\title{
Latent Autoimmune Diabetes in Adults Complicated by Persistent Isolated Glucosuria in the Absence of Hyperglycemia
}

\section{Kosuke Inoue*, Yuya Tsurutani, Chiho Sugisawa, Sachiko Suematsu, Jun Saito, Masao Omura, Tetsuo Nishikawa}

Endocrinology and Diabetes Center, Yokohama Rosai Hospital, Yokohama, Japan

Email: *koinoue-tky@umin.ac.jp

How to cite this paper: Inoue, K., Tsurutani, Y., Sugisawa, C., Suematsu, S., Saito, J., Omura, M. and Nishikawa, T. (2017) Latent Autoimmune Diabetes in Adults Complicated by Persistent Isolated Glucosuria in the Absence of Hyperglycemia. Case Reports in Clinical Medicine, 6, 133-136. https://doi.org/10.4236/crcm.2017.65012

Received: April 1, 2017

Accepted: May 20, 2017

Published: May 23, 2017

Copyright $\odot 2017$ by authors and Scientific Research Publishing Inc. This work is licensed under the Creative Commons Attribution International License (CC BY 4.0).

http://creativecommons.org/licenses/by/4.0/

(c) $\underset{\mathrm{EY}}{\text { (i) Open Access }}$

\begin{abstract}
Latent autoimmune diabetes in adults (LADA) is an autoimmune diabetes of adult-onset with the presence of diabetes associated autoantibodies. Familial renal glucosuria (FRG) is an inherited renal tubular disorder that causes persistent isolated glucosuria in the absence of hyperglycemia. We report a novel case of LADA and certain FRG. A 44-year-old man was admitted to our hospital for uncontrolled diabetes. Before admission, he had never suffered from diabetic coma and showed an improvement in HbAlc only with diet therapy. His $\mathrm{HbAlc}$ was $11.9 \%$ (107 $\mathrm{mmol} / \mathrm{mol})$, and anti-glutamic acid decarboxylase antibody was $13.0 \mathrm{U} / \mathrm{mL}$. A glucagon stimulation test showed the decrease of insulin secretion: plasma C-peptide (CPR) $0 \mathrm{~min}, 0.69 \mathrm{ng} / \mathrm{mL}$; CPR $6 \mathrm{~min}$, $0.90 \mathrm{ng} / \mathrm{mL}$. Analysis of genomic DNA revealed a novel heterozygous mutation in the SGLT2 coding gene, SLC5A2 (c.875G >A, p.Cys292Tyr), which was assessed as probably damaging with a score of 0.998 (sensitivity: 0.27 ; specificity: 0.99) by an in silico analysis. Therefore, he was diagnosed with LADA and certain FRG. He has not shown any symptoms and his HbAlc improved to $6.4 \%(46 \mathrm{mmol} / \mathrm{mol})$ three months after the introduction of insulin therapy. Our case clearly implies the clinical effectiveness of SGLT2 inhibition in patients with LADA.
\end{abstract}

\section{Keywords}

Latent Autoimmune Diabetes in Adults (LADA), Familial Renal Glucosuria (FRG), SLC5A2 Mutation, Sodium-Glucose Cotransporter 2 (SGLT2), Insulin Therapy

\section{Introduction}

Latent autoimmune diabetes in adults (LADA) accounts for $2 \%-12 \%$ of all cases 
of diabetes [1] [2]. It is important to distinguish LADA from type 2 diabetes because patients with LADA have a higher probability of requiring insulin therapy due to a relatively rapid deterioration of pancreatic $\beta$-cell function compared to patients with type 2 diabetes [2]. Familial renal glucosuria (FRG) is an inherited renal tubular disorder that causes persistent isolated glucosuria in the absence of hyperglycemia [3]. It has been known that mutations in the sodium-glucose cotransporter 2 (SGLT2) coding gene, $S L C 5 A 2$, were responsible for the disorder [4]. Herein, we report a novel case of LADA and certain FRG.

\section{Case Report}

A 44-year-old man was admitted to our hospital for uncontrolled diabetes for two years. His HbAlc was $12.0 \%$ (108 $\mathrm{mmol} / \mathrm{mol}) 18$ months before admission, which improved to $6.4 \%(46 \mathrm{mmol} / \mathrm{mol})$ following a diet therapy for six months, and deteriorated to $12.0 \%(108 \mathrm{mmol} / \mathrm{mol})$ again three months before admission. The patient had symptoms of polyuria, polydipsia, and unintended weight loss (8 kg/year). His past medical history was unremarkable and he had not taken any medication. However, the patient, his mother, and his 14-year-old son repeatedly presented with glucosuria despite normal blood glucose concentrations in their annual health check-up. There was no family history of diabetes. At the time of admission, his height was $168 \mathrm{~cm}$ and his weight was $57 \mathrm{~kg}$; his blood pressure was normal. The patient presented with the following levels: HbAlc, 11.9\% (107 mmol/mol); and anti-glutamic acid decarboxylase (GAD) antibody (measured with an enzyme linked immunosorbent assay), $13.0 \mathrm{U} / \mathrm{mL}$ (normal range, $<5.0 \mathrm{U} / \mathrm{mL}$ ). A glucagon stimulation test revealed the following results: plasma C-peptide (CPR) $0 \mathrm{~min}, 0.69 \mathrm{ng} / \mathrm{mL}$; CPR $6 \mathrm{~min}, 0.90 \mathrm{ng} / \mathrm{mL}$; plasma glucose (PG) $0 \mathrm{~min}, 102 \mathrm{mg} / \mathrm{dL}$; PG $6 \mathrm{~min}, 123 \mathrm{mg} / \mathrm{dL}$. He was diagnosed with LADA and was initiated on intensive insulin therapy with alpha-glucosidase inhibitors to preserve $\beta$-cell function [5]. His human leukocyte antigen (HLA) class II haplotypes were $D R B 1{ }^{*} 04: 05-D Q B 1{ }^{*} 04: 01$, which was concordant with the diagnosis of LADA [6]. PG was controlled to an average of 150 $\mathrm{mg} / \mathrm{dL}$ by an insulin injection and was monitored using continuous glucose monitoring. Urinary glucose and sodium levels were $15.8 \mathrm{~g} /$ day and $114.1 \mathrm{mEq} /$ day. Analysis of genomic DNA from his blood samples revealed a novel heterozygous $S L C 5 A 2$ mutation (c.875G $>$ A, p.Cys292Tyr). Therefore, the patient was also diagnosed with certain FRG. He has not shown any symptoms and his HbAlc improved to $6.4 \%(46 \mathrm{mmol} / \mathrm{mol})$ three months after the introduction of insulin therapy.

\section{Discussion}

To the best of our knowledge, this is the first case report of LADA complicated by persistent isolated glucosuria in the absence of hyperglycemia. We thought that his persistent isolated glucosuria due to mutations in the SGLT2 coding gene, $S L C 5 A 2$, assisted in maintaining glycemic control and pancreatic $\beta$-cell function. 
LADA is an autoimmune diabetes of adult-onset with the presence of diabetes associated autoantibodies, which may not initially require insulin therapy [1] [2]. Turner et al. showed that $94 \%$ of patients with LADA required insulin therapy by 6 years, and time to insulin dependence was more rapid in patients $<45$ years old than in older cases [7]. The other previous study showed that the degrees of autoimmunity and loss of $\beta$-cell function were related to the need for insulin therapy [8]. However, to date, the treatment in patients with LADA has not been established: the clinical effectiveness of early introduction of insulin therapy for them is still controvertial [2].

FRG is characterized by abnormal urinary glucose excretion in the absence of hyperglycemia [3]. It is a rare disease caused by an isolated renal tubular disorder, not accompanied by other proximal tubular transport abnormalitiess and renal dysfunction [3]. Therefore, patients with FRG are generally asymptomatic, and do not need medical intervention. The SLC5A2 mutation has been confirmed to be responsible for the large majority of FRG, which explains the mechanism of FRG as a result from a defect in SGLT2 [9]. Although the SLC5A2 mutation (c.875G > A, p.Cys292Tyr) in the present case has not been reported in patients with FRG, it was assessed as probably damaging with a score of 0.998 (sensitivity: 0.27; specificity: 0.99 ) by an in silico analysis.

Fortunately, our patient had never suffered from diabetic coma and showed improvement in $\mathrm{HbA1c}$ only with diet therapy, despite decreased insulin secretion. Considering that it has been recently reported that SGLT2 inhibitors have a positive effect on pancreatic $\beta$-cell function and glycemic control even in patients with type 1 diabetes as well as type 2 diabetes [10] [11], we assumed that SGLT2 inhibition might have some effective role for his clinical course. Further clinical and pathological studies are needed to clarify this effectiveness.

\section{Conclusion}

We experienced a novel case of LADA complicated by persistent isolated glucosuria in the absence of hyperglycemia. Our case clearly implies the clinical effectiveness of SGLT2 inhibition in patients with LADA.

\section{Acknowledgements}

We are grateful to the patient for the permission to publish this information.

\section{References}

[1] Tuomi, T., et al. (2014) The Many Faces of Diabetes: A Disease with Increasing Heterogeneity. The Lancet, 383, 1084-1094.

[2] Leslie, R.D., Williams, R. and Pozzilli, P. (2006) Clinical Review: Type 1 Diabetes and Latent Autoimmune Diabetes in Adults: One End of the Rainbow. The Journal of Clinical Endocrinology \& Metabolism, 91, 1654-1659. https://doi.org/10.1210/jc.2005-1623

[3] Calado, J., et al. (2006) Familial Renal Glucosuria: SLC5A2 Mutation Analysis and Evidence of Salt-Wasting. Kidney International, 69, 852-855.

https://doi.org/10.1038/sj.ki.5000194 
[4] Coady, M.J., et al. (2017) MAP17 Is a Necessary Activator of Renal Na+/Glucose Cotransporter SGLT2. Journal of the American Society of Nephrology, 28, 85-93. https://doi.org/10.1681/ASN.2015111282

[5] Maruyama, T., et al. (2003) Multicenter Prevention Trial of Slowly Progressive Type 1 Diabetes with Small Dose of Insulin (the Tokyo Study): Preliminary Report. Annals of the New York Academy of Sciences, 1005, 362-369. https://doi.org/10.1196/annals.1288.060

[6] Kawabata, Y., et al. (2002) Asian-Specific HLA Haplotypes Reveal Heterogeneity of the Contribution of HLA-DR and -DQ Haplotypes to Susceptibility to Type $1 \mathrm{Di}$ abetes. Diabetes, 51, 545-551. https://doi.org/10.2337/diabetes.51.2.545

[7] Turner, R., et al. (1997) UKPDS 25: Auto Antibodies to Islet-Cell Cytoplasm and Glutamic Acid Decarboxylase for Prediction of Insulin Requirement in Type 2 Diabetes. The Lancet, 350, 1288-1293.

[8] Radtke, M.A., et al. (2009) Heterogeneity of Patients with Latent Autoimmune Diabetes in Adults: Linkage to Autoimmunity Is Apparent Only in Those with Perceived Need for Insulin Treatment. Diabetes Care, 32, 245-250. https://doi.org/10.2337/dc08-1468

[9] Santer, R., et al. (2003) Molecular Analysis of the SGLT2 Gene in Patients with Renal Glucosuria. Journal of the American Society of Nephrology, 14, 2873-2882. https://doi.org/10.1097/01.ASN.0000092790.89332.D2

[10] Cheng, S.T., et al. (2016) The Effects of Empagliflozin, an SGLT2 Inhibitor, on Pancreatic Beta-Cell Mass and Glucose Homeostasis in Type 1 Diabetes. PLoS ONE, 11, e0147391. https://doi.org/10.1371/journal.pone.0147391

[11] Sands, A.T., et al. (2015) Sotagliflozin, a Dual SGLT1 and SGLT2 Inhibitor, as Adjunct Therapy to Insulin in Type 1 Diabetes. Diabetes Care, 38, 1181-1188. https://doi.org/10.2337/dc14-2806

\section{Submit or recommend next manuscript to SCIRP and we will provide best service for you:}

Accepting pre-submission inquiries through Email, Facebook, LinkedIn, Twitter, etc. A wide selection of journals (inclusive of 9 subjects, more than 200 journals)

Providing 24-hour high-quality service

User-friendly online submission system

Fair and swift peer-review system

Efficient typesetting and proofreading procedure

Display of the result of downloads and visits, as well as the number of cited articles

Maximum dissemination of your research work

Submit your manuscript at: http://papersubmission.scirp.org/

Or contact crcm@scirp.org 